\title{
Mowy o poście Bazylego Wielkiego w lacińskiej wersji Rufina z Akwilei
}

Posty znane były od wieków, zarówno w świecie grecko-rzymskim², jak i na Wschodzie. W Izraelu ustanowiony był - ponoć przez Mojżesza post jednodniowy w dzień pojednania, a w okresie niewoli praktykowano cztery posty. Te publiczne posty trwały jeden dzień, posty prywatne natomiast mogły być dłuższe. Ewangelia według świętego Łukasza poświadcza też posty częstsze i praktykowane regularnie w określone dni tygodnia (por. Łk 18,12). Didache (VIII 1) podaje, że gorliwi Żydzi pościli w poniedziałki i czwartki, a chrześcijanie - w środy i piątki. Post bowiem zajmował ważne miejsce również w praktyce starożytnego Kościoła ${ }^{3}$.

Zarazem zagadnienie rewaloryzacji postów, jak zauważa Franciszek Drączkowski, jest właściwie tak dawne, jak sama ich instytucja, co może poświadczać reforma praktyki postnej z czasów Izajasza (por. Iz 58,1-11) wspominana potem w Liście Barnaby, w pismach Justyna, Bazylego Wielkiego, Jana Kasjana, Augustyna czy Grzegorza Wielkiego ${ }^{4}$. Ojcowie ci podkreślali wartość wewnętrzną postów, krytykując pomijanie elementu duchowo-moralnego: „Najgorszym błędem [...] jest zawężenie postów wyłącznie do sfery fizycznej przy całkowitym pomijaniu sfery duchowej

1 Drhab. Dominika Budzanowska-Weglenda, profesor uczelni w Zakładzie Retoryki w Katedrze Literatury Staropolskiej w Instytucie Literaturoznawstwa na Wydziale Nauk Humanistycznych Uniwersytetu Kardynała Stefana Wyszyńskiego w Warszawie; e-mail: d.budzanowska@onet.pl; ORCID: 0000-0002-9030-9583.

2 Por. np. H. Wójtowicz, Asceza w hellenizmie, w: Wczesnochrześcijańska asceza. Zagadnienia wybrane, red. F. Drączkowski - J. Pałucki, Lublin 1993, s. 11.

3 Por. L. Nieścior, Post w czasach ojców Kościoła, w: Post jako praktyka duchowa. Ojcowie Kościoła o poście, opr. L. Nieścior, Kraków 2019, s. 11-12; M. Simon, Cywilizacja wczesnego chrześcijaństwa I-IV w., tł. E. Bąkowska, Warszawa 1992, s. 297-298.

4 Por. F. Drączkowski, Rewaloryzacja idei postów w nauczaniu Ojców Kościoła, w: Asceza, odczłowieczenie czy uczłowieczenie, red. W. Słomka, Lublin 1985, s. 125. 
człowieka"5. Ojcowie Kościoła zatem uwzględniali zasadę psychosomatycznej jedności natury ludzkiej i dlatego nawoływali „do zachowywania «postów prawdziwych», «postów doskonałych», «postów miłych i przyjemnych Bogu», postów prawdziwie uczłowieczonych"6.

Trzeba przy tym pamiętać, że ówczesne, starożytne traktaty poświęcone tematowi postu wykazują wzajemną zależność pisarzy, czytali oni bowiem „swoich poprzedników, powtarzali ich idee, a równocześnie po swojemu przedstawiali tę tematykę i wnosili coś innego" ", co jest bardzo widoczne w przypadku analizy mów Bazylego Wielkiego z kapadockiej Cezarei (329-379) i Rufina z Akwilei (345-410/411).

W czasach Augustyna, jak przypomina Heinrich Marti, kończy się epoka dwujęzyczności - wraz z podziałem państwa również w kulturze dokonuje się podział językowy: na Wschodzie dominuje greka, a na Zachodzie - łacina. Działają wówczas tacy thumacze, jak: Hieronim, Rufin, Eustatius, Ewagriusz, Anian, a także anonimowi pisarze. Próbują oni dla łacińskiego Zachodu uratować dorobek greckich pisarzy-teologów (listy, homilie, komentarze czy dzieła historyczne). Rufinowi nie udało się zbyt wiele przetłumaczyć. Patrząc na wydanie Migne'a, można to podsumować następująco: w Patrologia Graeca pisma Orygenesa zajmują siedem tomów, Bazylego - cztery, Grzegorza z Nazjanzu - cztery, a tłumaczenia Rufina tych trzech greckich ojców to około 2200 kolumn, czyli mniej niż dwa tomy ${ }^{8}$. Jednakże nie należy go nie doceniać. Ten mnich i kapłan jest bowiem autorem pism egzegetycznych (De benedictionibus patriarcharum libros duos i Expositio Symboli) oraz apologii związanych ze sporem z Hieronimem (wokół nauczania Orygenesa). Rufin napisał również dwie księgi dodane do przekładu Historia ecclesiastica Euzebiusza z Cezarei oraz dodatek do Myśli Sykstusa. Nie zachowały się Listy Rufina.

Znany jest on jednak głównie nie $\mathrm{z}$ tych samodzielnie napisanych dzieł, ale właśnie jako tłumacz z języka greckiego na łacinę, a skoro w owym czasie znajomość greki na Wschodzie znacząco zmalała, to dokonania Rufina w tej dziedzinie zasługują na uznanie. Prace nad przekładaniem greckich Ojców Kościoła na łacinę prowadził po powrocie z Ziemi Świętej do Italii w 397 roku. Tłumaczył wówczas Peri archōn (De principiis) Orygenesa, usuwając czy też poprawiając dogmatyczne błędy tego autora, co wzmogło konflikt między Rufinem

\footnotetext{
5 Por. Drączkowski, Rewaloryzacja idei postów w nauczaniu Ojców Kościoła, s. 127.

6 Drączkowski, Rewaloryzacja idei postów w nauczaniu Ojców Kościoła, s. 136.

7 Nieścior, Post w czasach ojców Kościoła, s. 11. Por. H. Marti, Einleitung, w: Rufin von Aquileia, De ieiunio I, II, ed. H. Marti, Leiden - New York - København - Köln 1989, s. XXIX. W kontekście mów Bazylego i Rufina o poście warto wspomnieć też o traktacie De Helia et ieiunio Ambrożego z Mediolanu oraz Contra Iulianum Augustyna z Hippony. Por. np. Marti, Einleitung, s. XXIII-XXVIII.
}

8 Por. Marti, Einleitung, s. XV. 
a Hieronimem (mimo ich dawnej przyjaźni). Zresztą Rufin przetłumaczył jeszcze wiele innych dzieł Orygenesa, głównie homilii i komentarzy, a ponadto wspomnianąjuż Historię Euzebiusza oraz Recognitiones (Rozpoznania) przypisywane Klemensowi Rzymskiemu, dwa zbiory sentencji (Ewagriusza z Pontu i filozofa Sekstusa), dzieło Historia monachorum in Aegypto Tymoteusza Archidiakona (?), De recta fide Adamantiosa (?), Reguty, dziewięć homilii i List 46 (Do upadtej mniszki) Bazylego Wielkiego, dziewięć homilii Grzegorza z Nazjanzu’. Te jego prace - prowadzone do około 407 roku $^{10}$ - mają z różnych względów istotne znaczenie dla literatury. Jednym z nich jest fakt, iż nie wszystkie greckie oryginały, np. dzieł Orygenesa, się zachowały.

W przekładach Rufina bardzo charakterystyczny jest jego stosunek do oryginału i język:

W literaturze chrześcijańskiej dotąd tłumaczono dzieła greckie w sposób dosłowny, a językiem przekładów była łacina potoczna. Dlatego mogły one nie podobać się wykształconym czytelnikom. Rufinus natomiast nawiązał do dawnej rzymskiej tradycji, według której przekład miał oddawać myśli oryginałów, a nie być dosłownym ich tłumaczeniem. Rufinus przywiązywał też duże znaczenie do dobrego stylu. Jego przekłady cieszyły się uznaniem. Biskupi Chromantius z Akwilei, Gaudencjusz z Brescii i Paulinus z Noli oceniali go życzliwie; później w pochwalnych słowach wypowiadali się o nim Kasjan i Gennadiusz ${ }^{11}$.

Dwie homilie Bazylego o poście Rufin ${ }^{12}$ również nie tylko częściowo przetłumaczy1 ${ }^{13}$ (zapewne właśnie do 407 roku w Akwilei ${ }^{14}$ albo wcześniej w 398

9 Por. np. B. Altaner - A. Stuiber, Patrologia, Warszawa 1990, s. 517-518; M. Cytowska - H. Szelest, Literatura rzymska. Okres Cesarstwa. Autorzy chrześcijańscy, Warszawa 1994, s. 129-131.

10 Por. SWP s. 347.

11 Cytowska - Szelest, Literatura rzymska, s. 131. Trzeba jednak też dodać, że ogromna popularność dzieł Hieronima usunęła na długi czas prace Rufina w cień. Por. np. SWP 347.

12 O problemach z ustaleniem autorstwa, por. np. Marti, Einleitung, s. XVII-XVIII.

13 Nie są to jedyne teksty Bazylego, które Rufin opracował na język łaciński. Por. np. B. Altaner, Aklateinische Übersetzungen von Basilius-Schriften, „Historisches Jahrbuch" 61 (1941) s. 208-212 (= Kleine Patristische Schriften, TU 83, Berlin 1967, s. 409-415); P.J. Fedwick, The Translations of the Works of Basil before 1400, w: Basil of Caesarea, Christian, Humanist, Ascetic, A Sixteen-Hundredth Anniversary Symposium, II, red. P.J. Fedwick, Toronto 1981, s. 455-473; A. Silvas, Rufinus'Translation Techniques in the ,Regula” Basili, Cambridge 2015.

14 Por. SWP 347. 
roku, kiedy był jeszcze w Rzymie, lub w latach 399-400, czyli już w Akwilei) ${ }^{15}$, ale też niekiedy znacząco poszerzył (czasem zaś przeciwnie: pominął pewne wątki), przedkładając wierność myśli nad dokładność w tłumaczeniu słów, co było cechą wspólną jego prac translatorskich: „Rufinus nie stara się o dokładny przekład oryginału greckiego. Traktuje go swobodnie; wprowadza do niego dodatki lub zmiany, jeśli te wydają mu się konieczne; dokonuje nawet pewnych poprawek, mając na względzie naukę ortodoksyjną"16.

Prawdziwość tych ocen potwierdza również sposób przełożenia albo raczej sparafrazowania lub wręcz pewnego rodzaju skomentowania przez Rufina homilii o poście Bazylego Wielkiego ${ }^{17}$. Celem niniejszego artykułu jest wstępne, a nie dokładne i całościowe, zestawienie owych homilii, by przedstawić treść zwłaszcza homilii Rufina i wskazać, które zagadnienia związane z postem szczególnie były ważne dla tego autora, który - jak się okazuje - nie był jedynie tłumaczem greckiego pierwowzoru.

\section{I homilia Rufina}

Bazyli ułożył obie homilie jako mowy przed pięcioma dniami postu, o czym wspomina sam grecki autor ${ }^{18}$. Przechodząc zaś do tekstu Rufina, uwagę najpierw warto zwrócić na adresata: I homilia (licząca cztery rozdziały) jest skierowana do ludu (Oratio ad populum de ieiunio). Autor rozpoczyna ją podobnie jak Bazyli, który pierwszą homilię o poście (liczącą jedenaście rozdziałów) otwiera fragmentem psalmu: „«Trąbcie na nowiu w trąbę, w dzień zacny uroczystego święta waszego» [por. Ps 81,4] mówi [Pismo]. Jest to rozkaz proroczy”"19. Rufin zaś zaczyna: „«Trąbcie na nowiu W trąbę, w dzień zacny uroczystego święta waszego», prorok poleca ludo-

15 Por. M. Huglo, Les anciennes versions latines des Homélies de saint Basile, RBen 64 (1954) s. 129, 132; Marti, Einleitung, s. XIX. Homilie Bazylego o poście powstały między 363 a 378 rokiem, może w 371 roku. Zob. P.J. Fedwick, A Chronology of the Life and Works of Basil of Caesarea, w: Basil of Caesarea, Christian, Humanist, Ascetic, A Sixteen-Hundredth Anniversary Symposium, II, red. P.J. Fedwick, Toronto 1981, s. 10.

16 Cytowska - Szelest, Literatura rzymska, s. 130. Por. np. J.N.D. Kelly, Początki doktryny chrześcijańskiej, tł. J. Mrukówna, Warszawa 1988, s. 105.

17 Por. np. Marti, Einleitung, s. XV, XXII-XXIII.

18 Por. Basilius Magnus, De ieiunio: homilia I 10; H. Marti, Rufinus'translation of St Basil's sermon on fasting, ,Studia Patristica” 16/2 (1985) s. 418-422.

19 Tłumaczenie homilii Bazylego według: Bazyli Wielki, Homilia I i II o poście, w: Św. Bazyli Wielki, Wybór homilij i kazań, tł. T. Sinko, Kraków 1947, s. 155-167, 168-176. Tłumaczenie homilii Rufina - własne. 
wi Izraela". Dodaje zatem od siebie adresata rozkazu-polecenia proroka - lud Izraela.

W dalszej części tej mowy Rufin jeszcze bardziej poszerza i zmienia tekst Bazylego. Ojciec kapadocki wzywa, by przeżywać prawdzi${ }^{w}{ }^{20}$ post, czyli zgodnie z zaleceniami Pisma Świętego, w tym proroka Izajasza, a nie według żydowskiego sposobu poszczenia: „nie w posępności, lecz pogodnie, jak przystoi świętym" (por. 1). Nazywa też post leczeniem $^{21}$. Z takiego właśnie rozumienia postu wynika ów brak posępności i pogodnie nastawienie, jak pisze Bazyli: „Nie zasępiaj się, gdy cię leczą. Głupią jest rzeczą nie cieszyć się zdrowiem duszy, lecz smucić się zmianą pokarmów i budzić pozór, że więcej cenimy przyjemność żołądka, niż troskę o duszę. Do brzucha bowiem wnosi przyjemność nasycenie, a post przynosi korzyść duszy. Wesel się, że lekarz dał lekarstwo na zniszczenie grzechu" (1).

Dokładniejsza analiza tego wstępnego fragmentu mowy Bazylego i Rufina pokazuje, jak ów drugi dodaje pewne treści od siebie. Bazyli pisze:

Nam zaś od wszelkiego narzędzia muzycznego wyraźniej zapowiadają odczytane słowa święto poprzedzające te dni. Poznaliśmy przecież łaskę postów od Izajasza, który z jednej strony odepchnął od siebie żydowski²2

20 Ten epitet występuje u Bazylego oraz u innych Ojców greckich i łacińskich, np. u Leona Wielkiego (por. Leo Magnus, Sermo 19, 3; PL 54, 186 B), gdzie podkreśla pozytywną wartość postów. Bazyli wyjaśnia, że „post prawdziwy to wyobcowanie się ze zła, powściągliwość języka, pohamowanie gniewu, oddalenie pożądliwości, obmów, kłamstw i krzywoprzysięstw. Powstrzymywanie się od tych wszystkich rzeczy oznacza realizacje postu prawdziwego. W takiej postawie zawiera się post prawdziwie piękny i wznosły" (Basilius Magnus, De ieiunio homilia II 7, PG 31, 196). Por. Basilius Magnus, De ieiunio homilia I 10, PG 31, 181 B. Por. Drączkowski, Rewaloryzacja idei postów, s. 130.

21 Myśl ta nie jest wybitnie związana z nauczaniem Bazylego, takie określenie występuje już wcześniej w pismach Ojców Kościoła. Jak zauważa Jerzy Pałucki: „Grzech w pismach Ojców Kościoła określany jest jako potrójne nieszczęście: śmierć, niewola i choroba. [...] W nauce Ojców Kościoła grzesznicy traktowani są jako chorzy, Chrystus zaś jest Boskim Lekarzem, który leczy słabości i niemoc ludzkich namiętności oraz grzechów. Nauka o Chrystusie, Boskim Lekarzu, znalazła szczególne rozwinięcie w pismach Klemensa Aleksandryjskiego" (J. Pałucki, Chrystus Boski Lekarz w pismach Klemensa Aleksandryjskiego, w: Wczesnochrześcijańska asceza. Zagadnienia wybrane, red. F. Drączkowski - J. Pałucki, Lublin 1993, s. 15).

22 Jak wyjaśnia Franciszek Drączkowski, w nomenklaturze Ojców Kościoła posty niewłaściwe, nieobejmujące sfery duchowo-moralnej człowieka, ale realizowane jedynie „w czczych gestach zewnętrznych”, czyli posty cielesne, obejmujące wyłącz- 
sposób poszczenia, z drugiej zaś pokazał nam prawdziwy post: „Nie pośćcie na swary i na zwady, lecz rozważcie wszelki związek niezbożności” (por. Iz 58,4.6).

Rufin zaś wyjaśnia, że nam także na wszelki „dźwięk rogu” i na wszelki „głos trąby” (por. 2Krn 15,14) Duch Święty ogłosił przez prorockie i (dodaje) ewangeliczne pisma, iż nadchodzi post i lecznicze dla duszy dni, mówiąc także przez innego proroka: „,wołajcie post, zapowiadajcie leczenie" (por. Jl 1,14; 2,15), a przez innego określając zasadę postu i jego sposób (modum), a nawet odrzucając ów żydowski post, o którym mówi: „nie pośćcie na swary ani na zwady” (Iz 58,4). Przestrzega, że bardzo wielu ludzi właśnie tym się zajmuje w dniach postów i to do tego stopnia, że aż wydaje się, iż dlatego ciału zabierają pokarm, aby karmić duszę szkodliwymi potrawami (czy wręcz uczt ami) obelg i dlatego tylko cierpią głód, łakną pokarmów, aby nasycić się zwadami. Odrzucając zatem tę postać postów, Pan przez proroka ogłasza: „nie taki post Ja wybrałem, mówi Pan, gdy człowiek umartwia swoją duszę, lecz rozwiąż wszelkie więzy niesprawiedliwości, dziel z serca swój chleb z głodnym, nagiego i bez domu wprowadź do twego domu. I wtedy nagle jak poranek wzejdzie twoje światło i twe zdrowie jak południe (por. Iz 58,5-8 Vul).

Rufin poszerza więc cytat z Księgi Izajasza i dodaje fragmenty z innych ksiąg biblijnych: Drugiej Księgi Kronik i Księgi Joela. Omawia cytat z Księgi Izajasza, wyjaśniając, że post nie może łączyć się kłótniami, lecz ma polegać na miłości bliźniego, na dzieleniu się z nim dobrami. Kolejne zdanie z homilii Bazylego: „A Pan powiada: «Nie bądźcie posępni, lecz obmyj oblicze swoje i namaść głowę swoją»" Rufin podobnie ,powiększa” zarówno w długości cytatu, jak i wprowadzającego go komentarza. Pisze, że to Pan w Ewangeliach w sposób doskonalszy i bardziej boski kształtuje to i pozostałe wskazania, gdy powtarza i mówi o poście: „Wy zaś kiedy pościcie, nie bądźcie posępni jak obłudnicy przybierający ponury wygląd twarzy. Ty zaś, gdy pościsz, namaść sobie głowę i umyj swoją twarz" (por. Mt 6,16-17). Wreszcie wezwanie Bazylego do radości („Usposóbmy się więc tak, jak nas nauczono, i nadchodzące dni obchodźmy nie w posępności, lecz pogodnie, jak przystoi świętym”) Rufin tak rozwija, eksponując jeszcze dobitniej ową radość płynącą ze zbawiennego znaczenia postu prowadzącego nas do zwycięstwa: „z takim więc usposobieniem przyjmujmy

nie sferę somatyczną człowieka, a zatem ,,posty nieużyteczne i próżne”, określane są jako ,posty żydowskie”. Por. Augustinus, Sermo 175, 1; 146, 1; Origenes, Homilia 10; Hermas, Pastor. Sim. V 1; Drączkowski, Rewaloryzacja idei postów, s. 126-127. 
łaskę postu, tak jak Pan uczy, i nie posępni i nie ze smętnym obliczem jakby obawiający się konieczności dni, lecz radośni i szczęśliwi; i powinniśmy z wszelką radością [tę] rzecz znosić, która dokonuje się dla nas w celu zwycięstwa i zbawienia".

Końcowy fragment rozdziału pierwszego u Bazylego brzmi:

Nikt małoduszny nie zdobywa wieńca, nikt smutny nie wnosi trofeów. Nie zasępiaj się, gdy cię leczą. Głupią jest rzeczą nie cieszyć się zdrowiem duszy, lecz smucić się zmianą pokarmów i budzić pozór, że więcej cenimy przyjemność brzucha, niż troskę o duszę. Do brzucha bowiem wnosi przyjemność nasycenie, a post przynosi korzyść duszy. Wesel się, że lekarz dał lekarstwo na zniszczenie grzechu. Jak bowiem robaki mnożące się we wnętrznościach dzieci, usuwa się zapomocą pewnych bardzo ostrych środków, tak grzech, kryjący się w głębinie, zabija w duszy wchodzący post, który naprawdę zasługuje na nazwę postu.

Rufin zaczyna bardzo podobnie, ale - wprowadzając dwa cytaty biblijne z Ewangelii według św. Mateusza i Listu św. Pawła do Rzymian oraz dodając kilka pytań retorycznych - podkreśla jeszcze wyraźniej niż Bazyli zbawienne i lecznicze znaczenie postu:

A kim jest [ten], kto posępny zdobyłby wieniec, kto smętny i ze strapionym obliczem tryumfowałby? Pomocne jest bowiem zwyciężanie ciała przez posty i tryumfowanie po zwycięstwie nad jego błędami [czy też grzechami - vitiis]. Któż kiedykolwiek się zasępia [z tego powodu], że jest leczony? Albo w jakiż sposób nie jest [czymś] obelżywym dopuszczać większy smutek z ograniczania pokarmów niż radość z uleczenia duszy? Jakimże jest ów umysł, którego bardziej zasmuca utrata przyjemności niż czyni szczęśliwym życie cnotliwe (virtutum), który ubolewa, że jest [mu] zabierane coś z brzucha - do tego bowiem skarbca składane są wszystkie owe zapasy pokarmów - i jest dodawane coś z „niebiańskich skarbców” powściągliwości, „których mól nie niszczy i gdzie złodzieje nie włamują się i nie kradną" (por. Mt 6,20). Radośni przeto i szczęśliwi przystąpmy do lekarza - naszego Boga, przyjmując lekarstwo postu, by móc przez cały rok wypędzać i wysuszać nazbierane szkodliwe płyny grzechów. Jak bowiem często widzimy, że u chłopców nazbierane wewnątrz zwierzątka [czy też pasożyty, robaki - bestiolas] są wyniszczane bardzo cierpkimi lekarstwami i napojami, tak post wyniszcza i zabija we wnętrznościach duszy naszej żyjące grzechy; zarazem także wywraca i obala owo prawo, które jest „w członkach moich walczące z prawem mojego umysłu i chce 
prowadzić mnie w niewolę pod prawo grzechu, które jest w moich członkach" (por. Rz 7,23).

Kolejny, drugi, rozdział homilii jest znacząco dłuższy u Rufina niż w greckim oryginale. Bazyli wyjaśnia:

„Namaść głowę swoją i obmyj oblicze swoje” (por. Mt 6,17). Do tajemniczych obrzędów wzywają cię te słowa. Namaszczony namaścił; obmyty obmył. Odnieś ten rozkaz do organów wewnętrznych. Namaść głowę świętym olejkiem, byś się stał uczestnikiem Pomazańca i tak przystępuj do postu. Nie zasępiaj swej twarzy, jak obłudnicy. A zasępia się twarz, gdy się wewnętrzne usposobienie zaciemnia udawanym wyglądem zewnętrznym, zasłania je kłamstwem, jak zasłoną. Hipokrytą nazywa się ten, co w teatrze bierze na siebie obcą maskę, nieraz maskę pana, będąc niewolnikiem, maskę króla, będąc człowiekiem prywatnym. Tak i w tym życiu, jak na scenie, wielu teatralizuje swoje żywoty, co innego nosząc w sercu, a co innego pokazując ludziom na widoku publicznym. Nie zaciemniaj więc oblicza. Jakim jesteś, takim się pokazuj. Nie przebieraj się za posępnego, goniąc za sławą z tego, że wydajesz się wstrzemięźliwym. Ani bowiem dobry uczynek nie przynosi pożytku, jeżeli go roztrąbisz, ani z postu publicznie rozgłoszonego nie ma żadnej korzyści. Albowiem co robi się dla popisu, nie przekazuje owocu na przyszły żywot, lecz kończy się na pochwale ludzkiej. Biegnij przeto pogodnie do daru postu. Stary to dar, ten post, i ani się nie przedawnia, ani nie starzeje, lecz się ciągle odnawia i rozkwita w pełni.

Rufin po raz kolejny znacząco poszerza wywód Bazylego. Najpierw rozwija wątek namaszczenia olejem podczas postu, nawiązując do namaszczenia „olejkiem radości” podczas sakramentu chrztu, potem przechodzi do wyjaśnienia, że głową namaszczaną jest sam Chrystus, i przypomina namaszczenie Jezusa przez kobietę drogim olejkiem:

Nawet ma słusznie dużo z tajemnicy [czy wręcz z sakramentu - sacramenti] sam sposób, jakim jesteśmy wprowadzani i kształtowani do poszczenia: „ty - mówi bowiem - kiedy pościsz, namaść głowę swoją i obmyj oblicze swoje" (por. Mt 6,17), przez co upomina nas, że olej królewski i olej kapłański, czy to ci, którzy jeszcze nie uzyskali [ich], katechumeni, pragną i pożądają, czy to ci, którzy zasłużyli już [by je] uzyskać, przez pamięć [o nich] zdobywają cnotę; oni bowiem zostali namaszczeni, mówi się, że zostali „namaszczeni olejkiem radości" [por. Ps 45,8]: gdzie został wygnany wszelki smutek, odeszło i cierpienie, i jęk. A zapewne w ten sposób ktoś namaszcza swoją głowę: jeśli „Chrystus jest głową mężczyzny”, którego głowę po- 
leca się namaścić, bez wątpienia poleca się namaścić Chrystusa. Kim jest ten, kto namaścił Chrystusa? Ewangelia nas poucza, że owa błogosławiona kobieta, która alabaster [tj. alabastrowy flakonik] ,z olejkiem wylała na głowę Jezusa" (por. Mt 26,7) i [tak] namaściła Go, bo [Ewangelia] nawet mówi, że „cały dom napełnił się wonią” (por. J 12,3); jeden zaś z uczniów, a konkretnie zdrajca Judasz, mówił: „Na co takie marnotrawstwo olejku? Przecież można było sprzedać i rozdać ubogim" (por. Mt 26,8-9); Jezus zaś, który wiedział, że czyn kobiety ma w sobie coś z tajemnicy/sakramentu (quid sacramenti), mówi: „Nie dręczcie kobiety. Dobry bowiem uczynek spełniła względem Mnie" (por. Mt 26,10); że [to] był dobry uczynek, wskazuje, mówiąc, że: „na pogrzeb Mnie przygotowała” (por. Mt 26,12). Przez to pokazywane jest, że namaszczenie Chrystusa oznacza przygotowanie Jego pochówku. Przygotowuje zaś pochówek Jezusa, [ten], który według apostoła [Pawła] „zadaje śmierć swoim ziemskim członkom: nierządowi, chciwości, lubieżności, złej żądzy" (por. Kol 3,5) i innym, [oraz ten,] który już „nie postępuje według ciała” (por. Rz 8,4), który uczynkami „ducha zadaje śmierć uczynkom ciała" (por. Rz 8,13) i, obym [to] pełniej mógł wyrazić, dla którego ,świat stał się ukrzyżowany i on sam dla świata” (por. Ga 6,14), zaiste [ten,] który „dla Chrystusa został ukrzyżowany” i nie tylko został „ukrzyżowany”, ale i „został pogrzebany” dla Niego (por. Rz 6,4; 6,6; Ga 2,19; Kol 2,12), on więc jest [tym], który namaszcza głowę swoją, poszcząc od błędów (vitiis) i wydziela w dobrych uczynkach ,dobrą woń Chrystusa" (por. 2Kor 2,15).

Oprócz tego przyrównania postu do namaszczenia olejkiem Rufin dodaje wywód o obmyciu oblicza, czyli objaśnia drugą część zdania z Ewangelii według św. Mateusza. Dodaje wiele cytatów z Nowego Testamentu:

Lecz [temu], kto pości, poleca się także obmyć swoje oblicze: jakie oblicze, jeśli nie to, dzięki któremu mówi się, że widać Boga? „Błogosławieni - bowiem czystego serca, bo oni Boga oglądać będą" (Mt 5,8). Owo oblicze, jeśliby miało jakąś „skazę czy zmarszczkę” (por. Ef 5,27), nie może oglądać Boga; jeśliby w owych oczach tkwiła drzazga grzechu (peccati - por. Mt 7,3), nie mogłyby już widzieć Boga. $\mathrm{Z}$ owego więc oblicza, to jest ze zmysłów (sensibus) duszy i tajemnicy (arcano) serca, powinniśmy sczyścić wszystkie brudy błędów/ grzechów (vitiorum), abyśmy według [słów] apostoła mogli, ,rozświetliwszy i odsłoniwszy to oblicze i na podobieństwo tego [Jego] obrazu przemienieni, oglądać chwałę Pana” (por. 2Kor 3,18). „Nie bądźcie - więc rzecze - posępni na swym obliczu, jak czynią hipokryci/obłudnicy" (por. Mt 6,16). A zasępia się to oblicze, o którym powyżej mówiliśmy, gdy usposobienie zewnętrzne udaje pobożność i jest zasłaniana zatruta wewnątrz gorycz niegodziwości. 
Rufin, podążając za greckim pierwowzorem, objaśnia też zachowanie hipokryty, stawiając go jako antywzór osoby poszczącej:

Wreszcie hipokrytą nazywa się ten, kto w teatrze, [grając] jakby osobę wyżej postawioną, choć jest inny [tj. nisko postawiony], udaje, że jest [kimś] innym, na przykład gdy gra osobę króla, choć sam jest plebejuszem, albo [osobę] pana, choć sam może jest niewolnikiem: tak więc w tym życiu, jak większość ludzi, jakby w teatrze posługuje się osobami, które [tylko grając jako aktor] udaje [że istnieją], a [są] nieprawdziwe, i, choć wewnątrz są czymś innym (aliud), pokazują się ludziom, że są czymś [jeszcze] innym (aliud).

Dalsze wyjaśnienia i zachęty Rufin także rozwija w stosunku do tekstu Bazylego, podając dłuższą listę wad i występków, których należy się wystrzegać, a pomijając pochwałę postu, „starego daru”, który wciąż jest „,nowy i w rozkwicie”:

„Ty - więc rzecze - nie bądź posępny na swym obliczu”: jakim jesteś, takim się pokazuj, nie udawaj smutnego i przygnębionego, wewnątrz zaś nie bądź targany płomieniami wszelkiego nieumiarkowania i gwałtowności, ani nie pokazuj, że ty jakoby powstrzymujesz się od twojego posiłku, a napadasz na obce domy, aby zarazem być pochwalonym za wstrzemięźliwość i potępionym za napaście. Pan więc daje jednocześnie dwa polecenia: ani nie [powinieneś] praktykować postu czy to na pokaz czy to dla pochwały, ani udawać obliczem i postawą pobożnego, byś [nie tylko] w umyśle i czynem mógł dokonywać przewrotu, lecz powstrzymywać się także od cielesnych pokarmów; dobre bowiem i pożyteczne jest poniżanie ciała i powściąganie pożądliwości, ujarzmianie rozpusty, porzucenie zbytku. O wiele zaś zacniejszym jest opanowanie niespokojnych i nieuporządkowanych poruszeń duszy: albowiem i dusza żyje rozrzutnie, gdy niesłusznie czegoś pragnie, gdy ponad miarę wywyższa się i pyszni, gdy poruszana jest podnietami zazdrości, gdy - zaniedbując swoje [dobra], które są niebiańskie - szuka ziemskich i nietrwałych, które są jej obce. Wszystkimi tymi poszczególnymi [rzeczami] trzeźwość i ustanawia właściwie sposób i granice postów, i [je] przyjmuje.

W trzecim rozdziale Rufin nie pomija wątku dawności postu - praktykowanego już w Starym Testamencie. Warto zestawić tekst Bazylego i Rufina, by pokazać, jak w tym rozdziale ów drugi dość wiernie podąża za myślą - choć nie zawsze za słownictwem - pierwszego: 


\section{Basilius Magnus, De ieiunio I 3}

Czy sądzisz, że ja jego [tj. postu] starodawność wywodzę z Prawa? I od Prawa starszy jest post. Jeśli trochę poczekasz, przekonasz się o prawdzie tych słów. Nie mniemaj, że dzień pojednania, nakazany Izraelowi w siódmym miesiącu na dziesiąty dzień miesiąca, jest początkiem postu. Chodźże tu tedy, przejdź historię i szukaj jego starodawności. Nie nowy to bowiem wynalazek, lecz skarb ojców.

Wszystko, co odznacza się dawnością, jest czcigodne. Szanuj siwiznę postu. Jest on rówieśnikiem pierwszych ludzi; przepisany został w raju. Pierwszy nakaz postu otrzymał Adam: „Z drzewa wiadomości złego i dobrego nie jedzcie”. A to „nie jedzcie” jest prawem. Gdyby Ewa zachowała była post od drzewa, nie potrzebowalibyśmy tego teraz postu. „Nie potrzeba bowiem zdrowym lekarza, ale chorym". Zachorowaliśmy przez grzech, leczmy się przez żal; żal zaś bez postu jest leniwy. „Przeklęta ziemia ciernie i osty będzie ci rodzić". Otrzymałeś rozkaz trapić się, nie żyć w przyjemnościach. Zapomocą postu usprawiedliw się Bogu. Ale i życie w raju jest obrazem postu, nietylko dlatego, że człowiek, jako uczestnik życia aniołów, podnosił się $\mathrm{Z}$ powodu poprzestawania na małym do podobieństwa $\mathrm{z}$ nimi, lecz także dlatego, że cokolwiek później myśl ludzka wynalazła, to jeszcze nie zostało wymyślone przez ludzi żyjących $\mathrm{w}$ raju, więc ani picie wina, ani zabijanie zwierząt na ofiarę, ani inne rzeczy, które brukają umysł ludzki.

\section{Rufinus, De ieiunio I 3}

Lecz być może wydaje się wam, że my znaleźliśmy jakiś nowy przepis jako rodzaj postów: ów dar jest bardzo dawny (perantiquum) i, z ojcowskiego dziedzictwa pochodząc, od dziadów i pradziadów bierze początek. Sądzicie być może, że ja od Prawa biorę sam jego początek, gdzie nakazuje się w Dniu Przebłagania ,dziesiątego dnia siódmego miesiąca" (por. Kpł 16,9; 23,27) stosować post. Podążajcie za mną przez epoki dziejów (per gradus histotiarum), a ja pokażę wam spośród wszystkich, którzy na tym świecie się narodzili, że początki postu są starodawne [i] jak jeg o siwizna i starodawność zasługuje na niewątpliwe uznanie wiary. Pierwsze prawo (prima lex) postu zostało dane nie na tym świecie, ale przed światem - w raju. To pierwsze polecenie otrzymał pierwszy człowiek stworzony przez Boga, mianowicie aby ,nie jeść z drzewa poznania dobra i zła” (por. Rdz 2,17), niejedzenie natomiast jest poszczeniem i zachowywaniem prawa wstrzemięźliwości. Po drugie, gdyby Ewa przestrzegała tego postu, my nigdy nie potrzebowalibyśmy owego postu, bo ,zdrowi nie potrzebują lekarza, lecz ci, którzy się źle mają" (por. Mt 9,12); źle się mamy i chorujemy z powodu karmienia się grzechem (per cibum peccati), możemy być leczeni i uzdrawiani przez post żalu (per ieiunium paenitentiae): przez pokarm został obrażony (offensus) Bóg, przez post może być udobruchany (mitigetur). Lecz teraz się zastanówmy, jaki jest i sam wyrok (sententia): „przeklęta - rzecze - ziemia w twoich działaniach, cierń i oset będzie ci rodziła" (por. Rdz 3,17-18). Czyż ten wyrok dozwala nam żyć w przyjemnościach (deliciari)? W tym jedzeniu okazało się, czym jesteśmy. Dlaczego nasze zło uważamy jakby za chwałę? Dlaczego z kary czynimy przyjemności? Dlaczego wyrok skazujący (condemnationem) uważamy za przyjemność (voluptatem)?

Bazyli i Rufin zatem zgodnie pouczają, że post jest starszy nawet od Prawa, bo już Adam w raju otrzymał nakaz postu, a dlatego że post jest aż 
tak starodawny, jest on godny czci i uznania. Obaj pisarze podkreślają też dwa momenty, w których Bóg ustanowił dla ludzi post, przy czym Rufin dokładniej je zaznacza, nazywając je prima lex, pierwszym prawem (,nie jeść z drzewa poznania dobra i zła") oraz jakby drugim prawem (leczenie się po grzechu postem), tu jednak nie używa rzeczownika lex i liczebnika porządkowego, ale przysłówka denique. W łacińskim tekście autor zawarł też inne zakończenie: nie nawiązuje do wątku uczestnictwa człowieka w życiu aniołów i podnoszenia się dzięki postowi, czyli poprzestawaniu na małym, do podobieństwa z nimi, za to pobudza czytelników i słuchaczy do refleksji, zadając kilka pytań retorycznych nawiązujących do zła, wyroku i kary.

Czwarty rozdział Rufin zaczyna podobnie jak Bazyli:

\section{Basilius Magnus, De ieiunio I 4}

Ponieważ nie zachowaliśmy postu, zostaliśmy wygnani z raju. Pośćmy więc, by wrócić do niego!
Rufinus, De ieiunio I 4

Zostaliśmy wygnani $\mathrm{z}$ raju, ponieważ nie pościliśmy: pośćmy teraz, aby powrócić do raju.

Następnie Bazyli nawiązuje do Ewy skuszonej przez węża: „Nie naśladuj nieposłuszeństwa Ewy, nie przyjmuj znowu za dorad[c]ę węża, który ci podsuwa kąsek dla oszczędzenia ciała". Rufin również przywoła tę scenę, a także odniesie się do Eliasza (przez Bazylego wspomnianego później, w rozdziale szóstym) i Łazarza (w tekście greckim wzmiankowanego dopiero w rozdziale dziesiątym), ale wywód swój w tym rozdziale inaczej poprowadzi i nim zakończy także całą mowę:

Lecz i samo życie całego raju jest postem: tam nigdy (nusquam) nie jest gotowane mięso, nie jest pite wino ani inne [nie dzieją się rzeczy], które służyłyby przyjemności ciała; lecz jest tam życie wspólne z aniołami, jednaki udział w niebiańskich cnotach. Ów sam wreszcie pokarm mądrości, jest tam w jakiś sposób nazywany, żywi się postami i służy mu się przez powściągliwość (per abstinentiam). Patrz, dzięki jakiemu postowi Eliasz wstąpił ku górze. Patrz, przez jakie jedzenie Ewa zeszła. Lecz spoglądaj i na sprawców obu działań i na doradców: tam sprawcą jedzenia i doradcą jest wąż, w wężu wręcz diabeł; tu sprawcą i wykonawcą [tego], by poszczący wszedł do nieba, [jest] Bóg. Korzystajmy więc i my z tej drogi, którą można wrócić do raju, a podejrzaną niech nam będzie tamta, która wygania człowieka z raju. Tej się trzymajmy, której wejście poznaliśmy otwarte poręką Pana naszego Jezusa Chrystusa mówiącego do łotra, gdy 
i on razem [z Nim] wisiał na drzewie [krzyża], że „dziś ze Mną będziesz w raju" (por. Łk 23,43). Albowiem nie mógłby nikt powrócić [do raju], gdyby On nie otworzył wierzącym wejścia. Tam wszedł i Łazarz, który ciągle, przez całe swoje życie nieustannie poszcząc, zaspokajał się jedynie pociechą „okruchów, które spadały ze stołu bogacza” (por. Łk 16,21). Tam także my staramy się wejść przez posty i uczynki miłosierdzia, byśmy zasłużyli otrzymać z drzewa życia, które jest „mądrością Boga” (por. 1Kor 1,30) i Jednorodzonym Synem Jego, Panem naszym Jezusem Chrystusem, „któremu jest chwała i moc” z Duchem Świętym na wieczne „wieki wieków. Amen” (por. 1P 4,11; Ap 1,6).

Pojawia się zatem wątek życia wspólnego z aniołami, wcześniej pominięty w tekście łacińskim (a obecny w greckim), Rufin jednak znacząco skraca mowę Bazylego, która liczy jeszcze siedem kolejnych rozdziałów. Warto wspomnieć, że w tekście greckim można znaleźć również takie wartościowe myśli związane z postem, a nieuwzględnione w tekście łacińskim:

- post posłuży nie tylko dobru duszy: dla ciała też jest lepiej jeść mniej i nie być obciążonym, potrawy kosztowne i urozmaicone przyczyniają się do chorób (por. De ieiunio I 4);

- w raju nie znano wina, to dopiero Noe zasadził winnicę i się potem upił, nie znając jeszcze umiaru w piciu (por. De ieiunio I 5);

- post jest nieprzerwaną tradycją przekazywaną z ojca na syna (por. De ieiunio I 4);

- znaczenie postu pokazują liczne przykłady: Mojżesz dzięki postowi zbliżył się do Boga i otrzymał przykazania, a pod górą obżarstwo sprowadziło grzech bałwochwalstwa, bo obżarstwo i pijaństwo niszczy zbawienie (por. De ieiunio I 5), jedna potrawa oddała Ezawa $\mathrm{w}$ niewolę brata, modlitwa połączona $\mathrm{z}$ postem podarowała matce syna - Samuela, post matki uczynił Samsona niezwyciężonym, post przygotował Eliasza na spotkanie z Bogiem, post uratował życie Elizeusza, młodzieńców w Babilonie post chronił przed płomieniami (por. De ieiunio I 6), Daniel nawet lwy nauczył pościć (por. De ieiunio I 7);

- post rodzi proroków, umacnia potężnych, daje mądrość prawodawcom, jest strażą duszy, bezpiecznym współmieszkańcem ciała, bronią bohaterów, ćwiczeniem zapaśników, odpiera pokusy, namaszcza do pobożności, towarzyszy trzeźwości, uczy wstrzemięźliwości, męstwa, spokoju, uświęca, post prowadzi do życia według Boga (por. De ieiunio I 6);

- post odprowadza modlitwę do nieba, stając się jakby jej skrzydłem w locie do nieba (por. De ieiunio I 7); 
- post do domów wprowadza zdrowie, bo uzdrawia relacje w rodzinie, leczy z zazdrości, rozrzutności, chroni przed lichwą; daje wytchnienie służbie (por. De ieiunio I 7-8), uczy wdzięczności dla Stwórcy za Jego dary (por. De ieiunio I 8);

- post daje również zdrowie całemu ciału (por. De ieiunio I 9);

- Jezus też pościł - właściwie całe Jego życie było postem, przez co nam pokazał, że post jest obroną przed pokusami i napaściami diabła (por. De ieiunio I 9);

- jeżeli chcesz uczynić silnym umysł, poskramiaj ciało postem (por. De ieiunio I 9);

- post wzmaga pragnienie stołu niebieskiego, ,,anielskiego chleba”, oraz uczestnictwa w darach duchowych (por. De ieiunio I 9);

- post służy życiu małżeńskiemu - uczy umiarkowania w pożyciu, daje harmonijny spokój i wytrwanie w modlitwie (por. De ieiunio I 9);

- post służy też całej społeczności, daje jej spokój (por. De ieiunio I 11);

- prawdziwy post to nie tylko powstrzymanie się od jedzenia, ale to oddalenie się od złego, zatem należy odpuścić bliźniemu, nie gniewać się, nie procesować się, oddalić smutek i strach oraz wszelki afekt (por. De ieiunio I 10);

- do pięciu dni postu trzeba się przygotować przez wstrzemięźliwość, nie wolno więc upijać się przed nim, pijaństwo odpędza Pana i Jego duchowe dary (por. De ieiunio I 10-11), należy pomagać potrzebującym (por. De ieiunio I 10).

Do niektórych wątków z tej mowy Bazylego Rufin powraca jeszcze w swojej drugiej homilii - De eadem re dictio secunda.

\section{II homilia Rufina}

Kolejną homilię „na ten sam temat”, czyli o poście, Rufin zaczyna samodzielnie, to znaczy bez nawiązywania do mowy Bazylego. Dwa pierwsze rozdziały można zatem określić jako całkowicie „Rufinowe”. Autor, a nie tylko tłumacz, wyjaśnia, że warto podjąć trud postu. W pierwszym rozdziale zauważa, iż owe zalecenia być może mają w sobie pewną trudność. Albowiem albo trzeba wyjść w nich naprzeciw pożytkowi ciała, albo opierać się samym afektom natury. Rufin przyrównuje tę sytuację do ofiary Abrahama, gdy boski głos rozkazał, żeby patriarcha złożył w ofierze jedynego syna (por. Rdz 22,2). Wówczas pojawił się naturalny afekt i doszło do wewnętrznego zmagania między 
ojcowskim usposobieniem a boskimi poleceniami: polecono mu złożyć w ofierze coś (quid), co jest dla niego wyjątkowe, i usilnie stara się on zachować owo coś - wyjątkowe dla każdego ojca, czyli dziedzica. Rufin stwierdza, że w tak ważnych sprawach jak najbardziej może dojść do walki takiego podwójnego afektu. Zarazem jednak podkreśla, że w owej sytuacji najstosowniejsze jest zwycięstwo odniesione dla Boga. Ponadto $\mathrm{w}$ zaleceniach dotyczących postu nie tylko nie ma niczego, co w naturalny sposób by się sprzeciwiało, ale wręcz wszystko w nim się zgadza z potrzebami i pożytkiem ciała. Przede wszystkim bowiem dusza odżywia się, gdy postną i trzeźwą posługą ciała sobie pomaga i służy w dziełach cnoty. Oprócz owych duchowych argumentów Rufin podaje, że post także jest potrzebny i pożyteczny dla ciała. Albowiem, jak przekonuje, ciało jest wtedy bardziej zdrowe i silne, inaczej niż w innych okresach, gdy na ciało naciskają potrawy, gdy jest ono napinane niestrawnością, gdy jest usypiane winem i obżarstwem, gdy ukrywa się „wczorajsze pijaństwo" 23 czy też ciało ociężałe od jakichś nocnych wzdęć zionie obrzydliwym smrodem (foetidos spiritus). Tymczasem ciało, gdy żywi się skromnym posiłkiem wystarczającym do zaspokojenia głodu, jest zdolne i gotowe do każdego działania i wszelkiej posługi. Dlatego Rufin wzywa najukochańszych braci (fratres dilectissi$m i$ ), by wspólne dobro duszy i ciała napełniali (compleamus) wspólnym staraniem (studio) i poświęceniem (devotione) i rozmyślali nad tym, że podczas postu są bardziej niż kiedykolwiek indziej ludźmi: „Jeśli będziesz musiał pracować, powstaniesz i żwawy, i gotowy, jeśli będziesz musiał iść, jeśli biec, okażesz się lekkim i szybkim".

W drugim rozdziale Rufin mocniej akcentuje duchowe pożytki płynące z postu. Przekonuje, że wtedy, gdy trzeba szukać Boga i badać sprawy boskie lub trzeba się wywiedzieć o delikatnych i duchowych kwestiach albo umysł ludzki pragnie zrozumieć coś z niebiańskiego sposobu myślenia (de caelesti ratione), dowiedzieć się o cnocie ducha, o zapobiegliwości, o szlachetnych i najlepszych naukach, to lepiej jest, jeśli naturalny ruch ducha nie jest uciskany żadnymi ciężarami posiłków i nie może być atakowany żadnymi przeszkodami (obicibus) stawianymi przez potrawy. Dążenie zaś ludzi do tego, by być podobnymi do Boga, Rufin uznaje za najważniejsze ich zadanie. Przejadanie się natomiast nazywa służbą żołądkowi i obżarstwu oraz przyczyną tego, że stajemy się bydlętami (pecora) i staramy się być podobni do dzikich zwierząt (beluis), którym natura pozwoliła być pochylonymi w dół (prona) i spoglądać w ziemię

23 Por. np. Seneca, Epistulae morales ad Lucilium 122, 2; Seneca, De brevitate vitae 14, 4: crapula hesterna. 
oraz słuchać się żołądka²4. Rufin powołuje się na ewangeliczne przykazanie Pana: „Baczcie, aby wasze serca nie były ociężałe wskutek opilstwa i pijaństwa" (in crapula et ebrietate - por. Łk 21,34) oraz na słowa Pawła Apostoła $\mathrm{z}$ dwóch jego listów: „królestwo Boże bowiem nie jest jedzeniem i napojem, ale sprawiedliwością i pokojem, i radością w Duchu Świętym” (por. Rz 14,17) oraz ,ani bowiem nie będziemy bogaci, jeśli będziemy jeść, ani ubodzy, jeśli nie będziemy jeść; pokarm dla żołądka, żołądek dla pokarmu, Bóg zaś unicestwi i jedno, i drugie" (por. 1Kor 8,8; 6,13). Zadając pytania słuchaczom i czytelnikom, Rufin wyjaśnia, że w swojej zachęcie do praktykowania postu nie odmawia życiu pociech oraz nie zabiera z niego i nie zakazuje tego, co „Bóg stworzył, by wierzący przyjmowali z dziękczynieniem" (por. 1Tm 4,3), lecz wzywa, byśmy poszukiwali miary, i uczy o umiarkowaniu. Za wzór stawia prorokinię Annę, która nieustannie trwała na postach i modlitwie. Jednak, znając słabość ludzką, Rufin zaleca, by zachowywać post przynajmniej w wyznaczone dni:

I choćby cały czas naszego życia dla nas, którzy nazywamy się „sługami Boga" (por. Rz 6,22), którzy jesteśmy uznawani za godnych noszenia miana Chrystusa, którzy zapewniliśmy, że „z Chrystusem zostaliśmy ukrzyżowani” (por. Rz 6,6; Ga 2,19) i „pogrzebani”, i że „zmartwychwstaliśmy z Chrystusem”, abyśmy „wiedli nowe życie” (por. Rz 6,4; Kol 3,1), był równy pod względem powściągliwości życia i [choćbyśmy] trwali w trzeźwości przez cały czas i byli wolni dla Słowa Boga i [mogli] „nad Jego Prawem rozmyślać dniem i nocą" (por. Ps 1,2), bo i sam przez proroka mówi: „bądźcie wolni i popatrzcie, bo Ja jestem Bogiem” (por. Ps 46,11), chociażby więc to było pożyteczne (expediret), jednak skoro ludzka słabość jeszcze nie może „patrzeć po nałożeniu zasłony” (por. 2Kor 3,13-18; Wj 34,33) w świętym świętych i trwać nieprzerwanie w świątyni Boga na postach i modlitwach, jak czyniła święta Anna (por. Łk 2,37), [to] przynajmniej zachowujmy z większą starannością i dbałością owe dni leczenia i pielęgnowania całego roku, abyśmy mogli je przyjąć jak jakiś zaczyn (fermentum) i całego roku ciasto (massam) (por. 1Kor 5,6) uwielbienia i pobożności (venerationis ac religionis).

24 Prosta i ku niebu zwrócona postawa ludzkiego ciała jest toposem z zakresu ,godności człowieka", o czym pisze Juliusz Domański, przywołując głównie fragmenty twórczości Owidiusza i Maniliusza. Por. J. Domański, Z dawnych rozważań o marności i pogardzie świata oraz nędzy i godności człowieka, Warszawa 1997, s. 83-85. Wątek ten jest obecny u wielu pisarzy starożytnych. Por. np. Seneca, Epistulae morales ad Lucilium 92, 30; Sallustius, Bellum Catilinae 1, 1. 
Ów post ma polegać nie tylko na ograniczeniu pokarmów, ale także na oddaleniu się czy wręcz oddzieleniu się od światowych trosk: od interesów, handlu, zysków, towarów, rachunków, czego celem jest „,wyruszenie ze świata do Boga" (saeculo proficiscamur ad deum). W poście ważne jest, by przez pobożne czytanie (per lectionem divinam), przez modlitwę, przez Słowo Boga, ,,przez psalmy, przez hymny i pieśni pełne ducha" (por. Kol 3,16), przez trzeźwość umysłu, przez skromność ciała (per pudicitiam corporis), przez czystość ducha i prostotę zakorzeniać się w samych tajemnicach (arcanis) Boga i Jego głębinach (por. De ieiunio II 2).

Kolejne i zarazem ostatnie dwa rozdziały nawiązują do tekstu greckiego, lecz nie do drugiej mowy, ale nadal do pierwszej. W trzecim rozdziale Rufin czerpie kolejno z rozdziałów piątego i szóstego pierwszej mowy Bazylego. Podobnie do poprzednika zapowiada, że teraz sięgnie do „kilku z wielu” dawnych przykładów, by swym słuchaczom (czy czytelnikom) została dana większa moc użyteczności postu i wstrzemięźliwości i aby wierzono, że dobro postu wypływa ze starodawnych źródeł. Owa dawność postu jest także jakby dziedziczona, bo wszak wszyscy święci posiadali „,starodawne i dziedziczne” dobro (antiquum et hereditarium bonum) postów, wciąż jest ono przelewane (transfusum est) na następne pokolenia poprzez szlachetne dziedziczenie (generosa successione). Jak u Bazylego, tak i u Rufina pierwszy przykład odnosi się do rajskiego postu - początek (origo) postu został zasadzony (plantata est) i pierwsze słowa Boga do człowieka wypowiedziane zostały odnośnie do postu: nigdy w raju nie jedzono mięso, nigdy nie upijano się winem. Dopiero po tym, jak ród ludzki został zasłużenie z powodu grzechu wyrzucony z raju i wygnany na ten świat, po wielu pokoleniach Noe wynalazł zarazem wino i winę (vinum et culpam). Drugi przykład, jak i u Bazylego, dotyczy Mojżesza, owego „wielkiego” (por. Wj 11,3) wodza i „przyjaciela” (por. Wj 33,11) Boga, który, gdy przyniósł do ludzi boskie słowa, a obecność Boga poświadczył dym góry i płomień, mrok i burza gwałtownego wichru, huk skał, „głosy gromów” (por. Ap 10,3), wstrząsy nieba, ufny w czterdziestodniowy post - choć boi się świat - on sam się nie boi i, wszedłszy w środek mgły i chmury (por. Wj 34,28), otrzymuje nie tylko Prawo litery, lecz i Ducha (por. 2Kor 3,6). Bazyli wątek ten nieco inaczej rozwinął, podkreślił bowiem, że Mojżesz dzięki postowi, uzbrojony w post, podszedł do góry, wszedł na dymiący szczyt i wszedł w ciemność. Również ,dzięki postowi otrzymał przykazania, spisane palcem Boga na tablicach". Rufin dodaje krótkie rozważanie o łasce postu dłuższego (gratia ieiunii prolixioris): 
[...] także pozostały lud został uświęcony i oczyszczony zachowywaniem trzech dni [postu] (por. Wj 19,11-16). Lecz owa wstrzemięźliwość tylko do tego wystarczyła, aby to, co się działo, [lud] zasłużył widzieć z daleka: owemu, który zniósł czterdzieści dni ciągłych postów, poleca się wejść na tę górę, gdzie był Bóg, i przebywać z aniołami Boga, dlatego że nawet natura ognia ustępuje poszczącemu. Chcesz zatem lepiej (verius) poznać, jakie są owoce brzucha poszczącego, a jakie sytego? Mojżesz, poszcząc, na górze przynależał do Boga, lud na dole, jedząc i pijąc, bożkom/idolom składał ofiary i nasycony winem i jedzeniem oddawał cześć głowie cielca, tak bowiem zostało napisane: po tym jak ,zamienili chwałę Boga na wizerunek cielca jedzącego siano" (por. Ps 106,20), „usiadł - rzecze - lud, aby jeść i pić, i wstali, żeby się bawić" (por. Wj 32,6). I owe pierwsze tablice Prawa „napisane palcem Boga” (por. Wj 31,18), które przyjęli dla trzeźwości, zniszczyli pijaństwem.

Również Bazyli przeciwstawia postawę Mojżesza i ludu, znacznie bardziej niż Rufin rozwijając ten wątek:

I na górze post przygotował prawodawstwo, a na dole obżarstwo sprowadziło szał bałwochwalstwa. „Usiadł bowiem lud jeść i pić i wstali grać” (por. Wj 32,6). Czterdziestodniowy pobyt z Bogiem poszczącego i modlącego się sługi w niwecz obróciło jedno upicie się winem. Albowiem tablice popisane palcem Boga, które otrzymał, rozbiło pijaństwo, gdy prorok osądził, że pijany lud nie godzien jest otrzymać prawa od Boga, W okamgnieniu ów lud, który przez największe cuda poznał Boga, stoczył się przez obżarstwo w szaleństwo bałwochwalstwa egipskiego. Porównaj z sobą te dwie rzeczy: jak post przywodzi do Boga i jak obżarstwo i pijaństwo gubi zbawienie!

Obaj zatem, pisząc o tym samym, inaczej rozkładają akcenty. Kolejne przykłady, zarówno w tekście greckim, jak i łacińskim (czerpiącym z homilii I 6) są już krótko wzmiankowane. Najpierw wspomniany jest Ezaw, potem Samuel, Samson, Eliasz, przy czym Bazyli przed omówieniem (dłuższym niż u Rufina) przykładu Eliasza dodaje fragment będący jakby pochwałą zbierającą czy podsumowującą argumenty dotyczące znaczenia i wpływu postu na życie poszczególnych ludzi: 


\section{Basilius Magnus, De ieiunio II I 6}

\section{Ezaw}

Co uczyniło nieczystym Ezawa i oddało go w niewolę brata? Czy nie jedna potrawa, za którą sprzedał pierworództwo?

\section{Samuel}

A Samuela, czy nie modlitwa połączona z postem, podarowała matce?

\section{Samson}

A cóż wielkiego bohatera Samsona uczyniło niezwyciężonym? Czy nie post, z którym się począł w łonie matki? „A cokolwiek się z winnicy rodzi, niechaj nie jada, wina i sycery niech nie pije".

Post proroków rodzi, umacnia potężnych; post prawodawcom daje mądrość, jest dobrą strażą duszy, bezpiecznym współmieszkańcem ciała, bronią bohaterów, ćwiczeniem zapaśników. On odpiera pokusy, on namaszcza do pobożności, jest domowym towarzyszem trzeźwości, sprawcą wstrzemięźliwości. W wojnach celuje męstwem, w pokoju uczy spokojności. Nazyrejczyka uświęca, wydoskonala na kapłana. Niemożliwą bowiem jest rzeczą, ażeby bez postu ośmielić się przystąpić do świętego obrzędu, nie tylko w mistycznym i prawdziwym nabożeństwie dzisiejszym, ale także w tym, które odprawiano w zapowiadających je figurach według prawa.

\section{Eliasz}

Post uczynił Eliasza widzem wielkiego widowiska. Czterdziestodniowym bowiem postem oczyściwszy duszę, w ten sposób w jaskini na Horeb stał się godnym widzenia Pana (por. 1Krl 19,8-14). Poszcząc, oddał wdowie syna, okazawszy się przez post wzmocnionym przeciw śmierci (por. $1 \mathrm{Krl}$ 17,8-24). Z poszczących ust wyszedł głos, który na trzy lata i sześć miesięcy zamknął niebo ludowi, przekraczającemu prawo. Aby bowiem zmiękczyć niepokonalne serce ludzi twardego ducha, zechciał i siebie samego skazać na wspólne znoszenie dolegliwości. Dlatego powiedział: „Żywie Pan, jeśli będzie woda na ziemi, jeśli nie według ust moich" (1Krl 17,1). I przez głód sprowadził post na cały lud, aby naprawić zło, powstałe ze zbytków i rozwiązłego życia.

\section{Rufinus, De ieiunio II 3}

Lecz i jak Ezaw stał się bezbożnikiem? (por. Hbr 12,16) Czyż nie dlatego że ,za jedną strawę sprzedał swój przywilej pierworództwa" (por. Rdz 25,30-34), które Jakub, młodszy brat, zdobył zapłatą wstrzemięźliwości (continentiae)?

Czyż także modlitwa-oczyszczona postem - wylana (profusa) przed Bogiem nie dała zasmuconej matce wielkiego proroka Samuela? (por. 1Sm 1,13-16)

Samson zaś mąż najmężniejszy i „nazirejczyk Boga" (por. Sdz 13,4-7.13-14) czyż nie został zrodzony dzięki postom i [czyż] dzięki większej wstrzemięźliwości (abstinentia) matki nie zostało większe męstwo przelane w [jej] potomka?

Wszystkim znany jest post Eliasza, którym zasłużył, by być wziętym ,przez wóz ognisty jakby do nieba" (por. $2 \mathrm{Krl} 2,1.11$ ). 
Bazyli przypomina także postać Elizeusza (por. 1Krl 19,8; $2 \mathrm{Krl} 4,38-41$ ) oraz młodzieńców w Babilonie (por. Dn 1,8-16; 3,23-24), do których to fragmentów Rufin już nie nawiązuje. Dopiero wspomnienie Daniela znów połączy oba teksty:

\section{Basilius Magnus, De ieiunio I 7}

\begin{abstract}
A Daniel, mąż pożądania, który przez trzy tygodnie nie jedząc chleba i nie pijąc wody (por. Dn 10,2-3), puszczony do jaskini nauczył nawet lwy pościć (Dn 6,20-23)? Nie mogły one wbić w niego zębów, jak gdyby był zrobiony z kamienia albo ze spiżu, albo z jakiegoś twardego materiału. Tak post zahartowal jego ciało, jak zanurzenie rozpalonego żelaza w zimnej wodzie, i uczynił je dla lwów niepokonanym. Nie otwarły nawet paszcz na świętego. Post zgasił moc ognia, zagrodził paszcze lwów.
\end{abstract}

\section{Rufinus, De ieiunio II 3}

Każdy wie, że dla Daniela wstrzemięźliwość (abstinentia) była jakby jakimś kluczem do tajemnic niebieskich (caelestium secretorum - por. Dn 10,3). Przez nią bowiem zostały mu odsłonięte „skarby mądrości i wiedzy” (por. Kol 2,3).

Rufin zatem kończy trzeci rozdział nawiązaniem do homilii Bazylego, ale pomija rozważania $\mathrm{z}$ greckiego pierwowzoru i w zupełnie innym kierunku prowadzi swoje: krótko łączy post z dostępem do tajemnic niebieskich oraz Bożej mądrości i wiedzy.

Ostatni rozdział bardzo luźno czerpie z pierwszej homilii Bazylego (aż z pięciu rozdziałów: 7-11). Rufin najbardziej eksponuje myśl z rozdziału dziesiątego i jedenastego wzywającego do przygotowania się do postu przez powstrzymywanie się od wyuzdania i pijaństwa, a zarazem przez zajęcie się pomaganiem potrzebującym (por. De ieiunio 10-11). Post przy tym nazywa - zgodnie z rzymską mentalnością i tradycją matką rodziny (mater familias, matrona) oraz - zapewne przywołując określenia znane z pism Cycerona, rzymskiego filozofa - królową cnót (regina virtutum):

Jest to słuszne (sane), że powinniśmy koniecznie upominać, byśmy, wprowadzając tę tak szlachetną matkę rodziny (matrem familias) tak zacnej i starodawnej odrośli, tak godną i mądrą oraz godną czci matkę (matronam) do naszych domów, nie zapełnili [ich] nieczystymi cudzołożnicami i haniebnymi ladacznicami: to bowiem czynią wszyscy, którzy jutro zamierzają podjąć posty, dziś mają czas na okrucieństwo i pijaństwo i szlachetne nadejście wstrzemięźliwości (abstinentia) plugawią najobrzydliwszymi zwiadowcami [tj. tymi uczynkami, które ją poprzedzają]. 
Dlatego zaiste, mając podjąć jak szlachetną królową w naszych domach - słusznie bowiem wstrzemięźliwość (abstinentia) jest „królową cnót ${ }^{25}$ uwieńczywszy - jak się mówi - drzwi" (coronatis postibus) ${ }^{26}$ i wszędzie roztoczywszy mocno pachnące wonie, gdy słusznie czynimy i najlepiej myślimy, przygotujemy dom naszego serca jako mieszkanie zasługujące na królewskie wejście (regio ingressu). Obyśmy się wam zgoła nie wydawali, że błądzimy, jeśli na pierwszym miejscu mówimy o jakichś rzeczach późniejszych jako koniecznych: dlatego mówimy o tych późniejszych, aby lepiej (tenacius) zapadły w pamięć. Prymitywny (incultum) i haniebny (turpe) jest post, który nie jest ozdabiany dziełami miłosierdzia, jako że i Pan „miłosierdzia raczej chce niż ofiary” (por. Oz 6,6; Mt 9,13; 12,7). I oczyszczenia z grzechów osąd/wyrok jest oddalony, który Pan określa, mówiąc: „dajcie jałmużnę, a oto wszystko będzie dla was czyste” (por. Łk 11,41). Nadto szpetnym się stanie handel, jeśli niejedzenie śniadania $\mathrm{z}$ racji postu obraca się w pieniądz, a także haniebną okazałaby się wstrzemięźliwość (abstinentia) [rozumiana jako] sposobność do zysku i będzie cielesny zysk dręczeniem ciała i nie biedak, lecz sakiewka twoja odczuje, że ty pościsz. Nie są to pobożne posty i nie mówi się, że przez takie przygotowywane [jest] Królestwo Boga, lecz przez te, o których Pan mówi: „byłem głodny, a daliście Mi jeść, byłem spragniony, a daliście Mi pić” (por. Mt 25,35) itd., tymi [słowami] przepowiadał: „pójdźcie, błogosławieni Ojca mojego, weźcie przygotowane wam królestwo"; owi są [tymi], o których mówi się, że „stoją po prawej stronie” króla i postawieni wśród jagniąt (agnorum) otrzymują królestwa wieczne (por. Mt 25,33-34). Oby zaś nie zdarzało się nam mówić o tym, że „mówi do tych, którzy są po lewej stronie: odejdźcie ode Mnie, przeklęci, w ogień wieczny, który Bóg przygotował diabłu i jego aniołom, bo byłem głodny, a nie daliście Mi jeść, byłem spragniony, a nie daliście Mi pić, byłem nagi, a nie przyodzialiście Mnie" (por. Mt 25,41-43) itd. Obu zaś czyn ujął jednym osądem, mówiąc, że: [ten,] „kto uczynił jednemu z tych najmniejszych, Mnie uczynił” (por. Mt 25,40), bez wątpienia: [ten,] „kto nie uczynił jednemu z tych najmniejszych, Mnie nie uczynił" (por. Mt 25,45). Jeślibyśmy w to wierzyli, najukochańsi, to nie sądzę, że ktoś tak byłby i bezbożny i niesprawiedliwy, aby - gdy Chrystus był głodny - nie mogę powiedzieć: nie dał z obfitości, lecz [ten,] kto, mając jeden tylko chleb w całym swoim wyżywieniu, nie podzieliłby się nim z Chrystusem głodnym, albo, mając jedną tylko tunikę, nie „okryłby nagiego Chrystusa”, odcinając jej

25 Por. Cicero, De officiis 3, 28: [...] iustitia; haec enim una virtus omnium est domina et regina virtutum.

26 Por. Quintilianus, Institutio oratoria 8, 6, 32: laureati postes. 
„środkową część” "27. I w jaki sposób teraz mamy odwagę i możemy nie dać nawet czegoś małego, odłożywszy wewnątrz szaty i zboże złożywszy w spichlerzu, dla potrzebujących, w których - [jak] jest powiedziane Chrystus jest tym, który odczuwa głód? To wszystko czyni nie żadna inna rzecz jak tylko niewiara (infidelitas). Aby więc i nasze modlitwy (orationes) stały się milsze Bogu przez modlitwy (orationes) biednych i żeby sumienie nasze nie zostało zranione przez to, że to, co zostało nam dane przez Boga, [jako] należne/właściwe (propria) sobie przypisujemy, i abyśmy nie zostali osądzeni na ścięcie jak drzewa niedające owoców - ,już bowiem siekiera do korzenia drzew jest przyłożona, aby każde drzewo, które nie wydaje dobrego owocu, zostało wycięte i w ogień wrzucone" (por. Mt 3,10) - zmieszajmy tłuszcze (adipes; por. Rdz 4,4; Kpł 3,16) miłosierdzia (misericordiae) z ofiarami naszych postów (ieiuniorum nostrorum sacrificiis), byśmy [zostali] znalezieni [jako] miłosierni (misericordes) i podążyli za miłosierdziem - przez Chrystusa króla i sędziego, Pana naszego, przez którego jest Ojcu z Duchem Świętym chwała i wieczność „na wieki wieków. Amen” (por. Ga 1,5; Rz 16,27; 1P 4,11; Ap 1,6).

Z pewnością u Rufina są ewidentne nawiązania do pierwszej homilii Bazylego, choć druga mowa nie jest rozbieżna treściowo z pierwszą, trudno wykluczyć i jej wpływ na rozważania Rufina o poście. Bazyli wszak także w niej zachęca do poszczenia, by „zdobyć wieniec sprawiedliwości”. Wyjaśnia, że post wzmacnia ćwiczącego się w pobożności. Przydaje duszy blask zdrowia duchowego i siły do walki z niewidzialnymi nieprzyjaciółmi-demonami (por. De ieiunio II 1). Jest więc pożyteczny w każdym czasie i dla wszystkich. Aniołowie ponadto gorliwiej pomagają poszczącym (por. De ieiunio II 2). Post jest przez Bazylego porównany w tej homilii do dobrej służby żołnierza, który znosi przykrości i walczy przepisowo (por. De ieiunio II 3).

Bazyli, podobnie jak w pierwszej homilii, tak również i w drugiej zaleca, by podczas postu nie smucić się (po żydowsku), lecz cieszyć się z duszą duchowym używaniem (por. De ieiunio II 3). Znowu też wzywa, by dobrze się przygotować do postu i nie upijać się przed nim (por. De ieiunio II 4). Podkreśla również, iż post jest ważny dla wszystkich członków rodziny (dzieci, starców, kobiet). Gdyby wszyscy pościli, na ziemi byłby pokój i nie byłoby wojen (por. De ieiunio II 5). Post służy też zdrowiu ciała. Bazyli krótko podaje ponownie przykłady świętych poszczących: Mojżesza, Samuela, Anny, Samsona, Eliasza (por. De ieiunio II 6). Powraca także definicja prawdziwego postu: „to oddalenie się od złego,

27 Por. Sulpicius Severus, Vita Sancti Martini 3, 2: mediam dividit partemque eius pauperi tribuit. 
wstrzemięźliwość języka, powstrzymanie się od gniewu, stłumienie pożądań, obmowy, kłamstwa, krzywoprzysięstwa" (por. De ieiunio II 7). Bazyli wzywa „Ucztujmy w Panu zapomocą rozważania słów Ducha, przyjmowania zbawiennych praw i wszystkich zasad poprawiających dusze" (por. De ieiunio II 8).

\section{Podsumowanie}

W tekstach mów Rufina zdecydowanie widać wpływ homilii Bazylego, niekiedy jest on bardzo wyraźny. Często jednak Rufin pewne wątki znacząco sam rozwija, a niektóre pomija, w ten sposób wręcz zacierając granice między tłumaczeniem i własnym tekstem ${ }^{28}$ autora, a nie tylko tłumacza. Zarówno Bazyli, jak i Rufin, a także jak większość Ojców Kościoła zwracają szczególną uwagę na moralno-duchowe nastawienie poszczącego oraz podkreślają duchowo-cielesne dobro i pożytek płynący z postu dla samego poszczącego i jego otoczenia: czas postu jest radosny, bo stanowią go lecznicze dla duszy dni - jest to czas obmycia z grzechów. Post więc nie może łączyć się kłótniami czy wyzyskiem, ale ma polegać na miłości bliźniego, na dzieleniu się z nim swymi dobrami. Bazyli i Rufin wzywają także do wstrzemięźliwości w piciu alkoholu i do czystości seksualnej - podobnie jak inni Ojcowie Kościoła, którzy także często piętnowali nadmierne korzystanie z wina i nadużycia sfery seksualnej ${ }^{29}$.

\section{Basil the Great's Speeches on the Fast in the Latin Version of Rufin of Aquileia}

(summary)

The fast has been known for centuries, both in the Greco-Roman world and in the ancient Orient. It also became a very important element of Christians' lives. The Church Fathers emphasized the intrinsic value of fasting, criticizing the omission of the spiritual and moral element of this practice. Their treatises on fast show the writers' interdependence, because they read their predecessors, repeated their ideas, but also presented the topic of fasting in their own way, which is also shown by a comparative analysis of the speeches of Basil the Great and Rufin of Aquileia. Rufin wrote his speeches under the clear influence of Basil's homilies. Rufin not only translated Basil's two homilies on fast, but also interpreted them. The Latin text often shows that Rufin develops some threads from the Greek text of Basil significantly and omits some. Both Basil and Rufin pay attention to the moral and spiritual attitude of the fasting

28 Por. Marti, Einleitung, s. XXIII.

29 Por. Nieścior, Post w czasach ojców Kościoła, s. 19-20. 
person and emphasize the spiritual and bodily goodness and benefit of fasting for the fasting person and his surroundings. They call for abstinence in drinking alcohol and for sexual purity.

Keywords: Basil of Caesarea; Saint Basil the Great; Rufin of Aquileia; speech; homily; fast; fasting practice

\section{Mowy o poście Bazylego Wielkiego w lacińskiej wersji Rufina z Akwilei}

(streszczenie)

Posty znane były od wieków, zarówno w świecie grecko-rzymskim, jak i na Wschodzie. Stały się też bardzo istotnym elementem życia chrześcijan. Ojcowie Kościoła podkreślali wartość wewnętrzną postów, krytykując pomijanie elementu duchowo-moralnego. Ich traktaty o poście wykazują wzajemną zależność pisarzy, czytali oni bowiem swoich poprzedników, powtarzali ich idee, ale i po swojemu przedstawiali temat postu, co wykazuje także analiza porównawcza mów Bazylego Wielkiego i Rufina z Akwilei. Rufin swoje mowy pisał pod wyraźnym wpływem homilii Bazylego. Rufin nie tylko przetłumaczył dwie homilie Bazylego o poście, ale je zinterpretował. Łaciński tekst często bowiem pokazuje, że Rufin pewne wątki z greckiego tekstu znacząco rozwija, a niektóre pomija. Zarówno Bazyli, jak i Rufin zwracają uwagę na moralno-duchowe nastawienie osoby poszczącej oraz podkreślają duchowo-cielesne dobro i pożytek płynący z postu dla samego poszczącego i jego otoczenia. Wzywają do wstrzemięźliwości w piciu alkoholu i do czystości seksualnej.

Słowa kluczowe: Bazyli z Cezarei; Bazyli Wielki; Rufin z Akwilei; mowa; homilia; post; praktyka postna

\section{Bibliografia}

\section{Źródla}

Basilius Magnus, De ieiunio: homilia I et II, PG 31, 164-184, 185-197, tł. T. Sinko, Św. Bazyli Wielki Homilia I i II o poście, w: Św. Bazyli Wielki, Wybór homilij i kazań, Kraków 1947, s. 155-167, 168-176.

Cicero, De officiis, ed. W. Miller, Cambridge - London 1913.

Quintilianus, Institutio oratoria, ed. H.E. Butler, Cambridge - London 1922.

Rufinus, De ieiunio I, II, ed. H. Marti, Leiden - New York - København - Köln 1989.

Sallustius, Bellum Catilinae, ed. A.W. Ahlberg, C. Sallusti Crispi Catilina, Iugurtha, Orationes Et Epistulae Excerptae De Historiis, Leipzig 1919.

Seneca, De brevitate vitae, ed. R.D. Reynolds, Dialogorum libri XII, Oxford 1977.

Seneca, Ad Lucilium Epistulae Morales, v. 1-3, ed. R.M. Gummere, Cambridge - London 1917-1925.

Sulpicius Severus, Vita Sancti Martini, ed. K. Halm, CSEL 1, Wien 1866. 


\section{Opracowania}

Altaner B., Aklateinische Übersetzungen von Basilius-Schriften, Historisches Jahrbuch 61 (1941) s. 208-212 (= Kleine Patristische Schriften, TU 83, Berlin 1967, s. 409-415).

Altaner B. - Stuiber A., Patrologia, Warszawa 1990.

Cytowska M. - Szelest H., Literatura rzymska. Okres Cesarstwa. Autorzy chrześcijańscy, Warszawa 1994.

Domański J., Z dawnych rozważań o marności i pogardzie świata oraz nędzy i godności człowieka, Warszawa 1997.

Drączkowski F., Rewaloryzacja idei postów w nauczaniu Ojców Kościoła, w: Asceza, odczłowieczenie czy uczłowieczenie, red. W. Słomka, Lublin 1985, s. 125-136.

Fedwick P.J., The Translations of the Works of Basil before 1400, w: Basil of Caesarea, Christian, Humanist, Ascetic, A Sixteen-Hundredth Anniversary Symposium, II, red. P.J. Fedwick, Toronto 1981, s. 439-512.

Fedwick P.J.,, A Chronology of the Life and Works of Basil of Caesarea, w: Basil of Caesarea, Christian, Humanist, Ascetic, A Sixteen-Hundredth Anniversary Symposium, II, red. P.J. Fedwick, Toronto 1981, s. 3-19.

Huglo M., Les anciennes versions latines des Homélies de saint Basile, RBen 64 (1954) s. $129-132$.

Kadžaia N., Les lectures du jê̂ne de Basile le Grand dans les recueils géorgiens anciens, „Orientalia christiana periodica” 53 (1987) s. 431-434.

Kelly J.N.D., Poczatki doktryny chrześcijańskiej, tł. J. Mrukówna, Warszawa 1988.

Marti H., Einleitung, w: Rufin von Aquileia, De ieiunio I, II, red. H. Marti, Leiden - New York - København - Köln 1989, s. XV-XXIX.

Marti H., Rufinus' translation of St Basil's sermon on fasting, „Studia patristica” 16/2 (1985) s. 418-422.

Nieścior L., Post w czasach ojców Kościoła, w: Post jako praktyka duchowa. Ojcowie Kościoła o poście, opr. L. Nieścior, Kraków 2019, s. 11-52.

Pałucki J., Chrystus Boski Lekarz w pismach Klemensa Aleksandryjskiego, w: Wczesnochrześcijańska asceza. Zagadnienia wybrane, red. F. Drączkowski - J. Pałucki, Lublin 1993, s. 15-34.

Silvas A., Rufinus' Translation Techniques in the Regula Basili, Cambridge 2015.

Simon M., Cywilizacja wczesnego chrześcijaństwa I-IV w., tł. E. Bąkowska, Warszawa 1992.

Szymusiak J.M. - Starowieyski M., Słownik wczesnochrześcijańskiego piśmiennictwa, Poznań 1971.

Wójtowicz H., Asceza w hellenizmie, w: Wczesnochrześcijańska asceza. Zagadnienia wybrane, red. F. Drączkowski - J. Pałucki, Lublin 1993, s. 9-14. 